\title{
Growth and Nutrition of Two Cultivars of Zinnia elegans Under Saline Conditions
}

\author{
Christy T. Carter ${ }^{1}$ \\ Tennessee Tech University, Department of Biology, 122 Pennebaker Hall, \\ Cookeville, TN 38505
}

Catherine M. Grieve

U.S. Salinity Laboratory, 450 W. Big Springs Road, Riverside, CA 92507

Additional index words. cut flowers, floriculture, greenhouse crop production, mineral nutrition, salinity, wastewater, zinnias

Abstract. Zinnia elegans, because of its economic value and the hardiness of its wild relatives, was selected as a potential salt-tolerant cut flower crop to grow in greenhouse systems using recycled agricultural wastewater. Using recycled wastewater for irrigation of cut flowers provides an alternative to high-quality water. This is especially important in coastal and inland growing regions of California where competition for high-quality water is increasing between urban and agricultural users and provides economic and environmental benefits because groundwater contamination is reduced or even prevented. A completely randomized design was used to determine the effects of water ionic composition and salinity on the growth and leaf mineral composition of Zinnia elegans. Two cultivars (Benary's Giant Salmon Rose and Benary's Giant Golden Yellow) were grown under irrigation with two different water ionic compositions mimicking dilutions of sea water (SWD) and concentrations of Colorado River water (CRW) at increasing salinity levels with electrical conductivities of 2.5 (control), $4.0,6.0,8.0$, and $10.0 \mathrm{dS} \cdot \mathrm{m}^{-1}$ in greenhouse sand tanks in Riverside, $\mathrm{CA}$. Leaf mineral concentrations were determined for calcium (Ca), magnesium (Mg), sodium ( Na), potassium (K), chlorine (Cl), total sulfur (S), and total phosphorus (P). At harvest, final plant measurements included time to flowering, stem length, stem diameter (recorded at the soil line), internode length (recorded at the middle of the stem), inflorescence diameter, ray length, plant shoot fresh weight, number of leaves per plant, and number of shoots per plant. For both cultivars, plant tissue concentrations of $\mathrm{Mg}, \mathrm{Cl}, \mathrm{Na}$, and total $\mathrm{S}$ increased as salinity increased in the irrigation water. Conversely, plant tissue concentrations of $\mathrm{Ca}, \mathrm{K}$, and total $\mathrm{P}$ decreased as salinity increased in the irrigation water. Both cultivars demonstrated high selectivity for $\mathrm{K}$ over Na as salinity increased in CRW and SWD with 'Golden Yellow' demonstrating a higher selectivity than 'Salmon Rose'. Additionally, measured growth parameters tended to decrease as salinity increased in both irrigation water types for both cultivars. Stem lengths of $79 \mathrm{~cm}$ and $51 \mathrm{~cm}$ were found for 'Salmon Rose' growing in $10 \mathrm{dS} \cdot \mathrm{m}^{-1}$ in concentrations of CRW and SWD, respectively. 'Golden Yellow' produced stem lengths of $74 \mathrm{~cm}$ and $46 \mathrm{~cm}$ in $10 \mathrm{dS} \cdot \mathrm{m}^{-1}$ in response to concentrations of CRW and SWD, respectively. Inflorescence diameters of both cultivars approximated $8.0 \mathrm{~cm}$ at the highest salinity for both water types. Although significant differences were found, the minimum of $46 \mathrm{~cm}$ indicates that marketable flowers can be produced using both water types at least as high as $10 \mathrm{dS} \cdot \mathrm{m}^{-1}$.

Cut flowers are an important agricultural crop in California. Historically, growers have used the highest quality water to irrigate many of these sensitive and non-consumable

\footnotetext{
Received for publication 23 Apr. 2010. Accepted for publication 1 June 2010.

We thank Donald A. Layfield for conducting plant and water mineral analyses and Phyllis Nash for statistical assistance. Doug Diaz screened for insect damage. John Draper assisted with data collection. Three anonymous reviewers provided helpful and insightful comments.

Mention of company names or products is for the benefit of the reader and does not imply endorsement, guarantee, or preferential treatment by the USDA or its agents.

${ }^{1}$ To whom reprint requests should be addressed; e-mail ctcarter@tntech.edu.
}

crops to produce superior flowers. In recent decades, however, there has been an increase in agricultural production overall and an increase in population. These phenomena, when coupled with diminishing sources of fresh water, continue to intensify competition for high-quality water. One solution for the agricultural industry, especially greenhouse growers, has been to use lower quality water and/or greenhouse effluents to irrigate their crops. Many growers have also found applications for saline or degraded wastewaters in their own operations that continue to allow them to produce high-quality marketable crops (Skimina, 1992). In many instances, growers can use lower quality water to produce crops of superior quality. Cut flowers, because they are non-consumable high-value crops, are ideal for a production system that uses degraded water having higher electrical conductivities for irrigation. Historically, most cut flowers have been considered to be glycophytes and were expected to have little or no salinity tolerance (Greenway and Munns, 1980). Production of crops under saline conditions does raise concerns given that salinity stress, either as a result of an osmotic or specific ion effect, can stunt growth, produce foliar injury, affect nutrient balance, impair root function, and distort flower growth (Valdez-Aguilar et al., 2009). Recent research now indicates that many cut flowers, including varieties of Matthiola incana, Antirrhinum majus, Celosia argentea, Limonium perezii, Limonium sinuatum, and Helianthus annuus, have proven levels of salinity tolerance (Carter and Grieve, 2006, 2008; Carter et al., 2005a, 2005b; Grieve et al., 2006, 2008; Monk and Peterson, 1961). Studies performed in Israel also show that cut flowers, Japanese limonium in particular, can be produced using irrigation water with electrical conductivities up to $11.5 \mathrm{dS} \cdot \mathrm{m}^{-1}$ (Shillo et al., 2002). In some instances, salinity exposure has proven benefits. Height control is an important quality issue for some floral crops. For example, when chrysanthemum and celosia are grown under non-saline conditions, the flowering stems are often excessively tall and weak. With proper management, salinity becomes an environmentally friendly alternative to chemical growth retardants to restrict height and strengthen stems (Carter et al., 2005a; Lee and van Iersel, 2008; Shillo et al., 2002).

It is also important for growers to understand how different combinations of salts will affect their crops. Flower growers in coastal regions of California will find it more useful to know how their crops will respond to increases in sodium chloride, the primary salt in sea water, given that sea water intrusion of groundwater is on the rise. Growers in the Imperial and Coachella Valleys of southern California will find it more useful to understand how sulfate-based salts of magnesium and calcium, in addition to sodium chloride, will affect their crops. Much of the irrigation water in this region is derived from the Colorado River watershed and contains nutrients and salts from agricultural runoff that increase the electrical conductivity (EC) of the water (Carter and Grieve, 2008; Carter et al., 2005a).

Zinnia elegans is native to Mexico and is grown commercially as a bedding plant and cut flower. It is known for its tolerance to hot and dry conditions (Dole and Wilkins, 1999). Zinnia is also an economically important crop in the United States. Because of its general tolerance to dry and saline environments and its economic importance, we selected zinnia to evaluate as a potentially salt-tolerant cut flower crop.

Specifically, our goals in this investigation were to: 1) determine whether marketable cut flowers of two zinnia cultivars could be produced under increasing salinity in a greenhouse environment; 2) determine whether differences were found in plant growth when plants were exposed to irrigation water dominated 
by either sulfate- or chloride-based salts; and 3) determine leaf mineral compositions of two zinnia cultivars when exposed to saline irrigation waters differing in ionic composition.

\section{Materials and Methods}

Growth in greenhouse conditions. Seeds of 'Benary's Giant Golden Yellow' and 'Benary's Giant Salmon Rose' were purchased from Johnny's Selected Seeds (Winslow, ME) and sown in each of 30 greenhouse sand tanks $(1.2 \times 0.6 \times 0.5 \mathrm{~m})$ at the U.S. Salinity Laboratory in Riverside, CA. A template was used to mark eight rows (spaced at $12 \mathrm{~cm}$ ) with 10 wells per row (spaced at 5 $\mathrm{cm}$ ) in each tank. Four adjacent rows were randomly assigned to 'Salmon Rose' and the remaining four were assigned to 'Golden Yellow' in each of the 30 tanks to help mitigate any potential position effects within the greenhouse. Two seeds were sown in each well on 8 June 2004. Seedlings were thinned to one seedling per well after cotyledons emerged within 1 week of planting resulting in 40 plants per cultivar per tank.

To determine the effects of water ionic composition and salinity on the growth on these two zinnia cultivars, we implemented a completely randomized experimental design with three replications per treatment. Thirty sand tanks provided three replicates of 10 treatments total. Two ionic water compositions were prepared to simulate saline wastewater resources prevalent in southern California at five target salinity levels [2.5 (control), 4.0, 6.0, 8.0, and $10.0 \mathrm{dS} \cdot \mathrm{m}^{-1}$. Dilutions of sea water were prepared with laboratory chemicals to simulate diluted well waters where sea water intrusion of groundwater has occurred in coastal regions of California. These preparations were constructed to ensure a $1: 1 \mathrm{Ca}: \mathrm{Mg}$ ratio so that adequate plant nutrition could be maintained (Carter and Grieve, 2008; Grattan and Grieve, 1999). The second water ionic composition was prepared to mimic estimates of the ion compositions of water imported from the Colorado River to the inland valleys of California and on simulations of what these water compositions would be on further concentrations by plant-water extractions and by evaporation (Suarez and Simunek, 1997) (Table 1).

Greenhouse sand tanks were filled with washed river sand that had an average bulk density of $1.4 \mathrm{Mg} \cdot \mathrm{m}^{-3}$. Tanks were irrigated twice daily at $0300 \mathrm{HR}$ and $0900 \mathrm{HR}$ for $5 \mathrm{~min}$ using an automated irrigation system that delivered water to the surface of the sand beginning when seeds were sown. After $9 \mathrm{~d}$, irrigation was switched to once per day at $1300 \mathrm{HR}$ for $5 \mathrm{~min}$. Water drained from each tank by gravity and collected into large 765-L subsurface reservoirs, each of which was connected to a specific sand tank. At saturation, volumetric water content in each tank was $0.34 \mathrm{~m}^{3} \cdot \mathrm{m}^{-3}$ and decreased to $0.1 \mathrm{~m}^{3} \cdot \mathrm{m}^{-3}$ once water drained. To maintain target salinity concentrations, water volume was automatically filled in the reservoirs daily to

Table 1. Target mineral concentrations (mM) of saline water solutions used to irrigate Zinnia elegans at increasing salinity $\left(\mathrm{dS} \cdot \mathrm{m}^{-1}\right)$.

\begin{tabular}{|c|c|c|c|c|c|c|c|}
\hline \multirow{2}{*}{$\begin{array}{l}\text { Electrical conductivity } \\
\left(\mathrm{dS} \cdot \mathrm{m}^{-1}\right)\end{array}$} & $\mathrm{Ca}^{2+}$ & $\mathrm{Mg}^{2+}$ & $\mathrm{Na}^{+}$ & $\mathrm{K}^{+}$ & $\mathrm{SO}_{4}{ }^{2-}$ & $\mathrm{Cl}^{-}$ & $\mathrm{NO}_{3}$ \\
\hline & \multicolumn{7}{|c|}{ (mM) } \\
\hline \multicolumn{8}{|l|}{$\begin{array}{l}\text { Concentrations of } \\
\text { Colorado River water }\end{array}$} \\
\hline 2.5 & 2.5 & 3.0 & 10.5 & 6.0 & 3.3 & 13.3 & 5.0 \\
\hline 4.0 & 3.9 & 6.1 & 20.9 & 6.0 & 6.7 & 27.5 & 5.0 \\
\hline 6.0 & 5.7 & 9.4 & 32.3 & 6.0 & 10.0 & 42.0 & 5.0 \\
\hline 8.0 & 7.6 & 12.7 & 43.6 & 6.0 & 13.6 & 57.2 & 5.0 \\
\hline 10.0 & 9.4 & 16.3 & 55.0 & 6.0 & 17.3 & 72.5 & 5.0 \\
\hline \multicolumn{8}{|l|}{ Sea water dilutions } \\
\hline 2.5 & 2.5 & 1.2 & 14.5 & 6.0 & 0.5 & 18.3 & 5.0 \\
\hline 4.0 & 2.5 & 2.3 & 27.4 & 6.0 & 0.9 & 35.0 & 5.0 \\
\hline 6.0 & 3.4 & 3.4 & 40.5 & 6.0 & 1.4 & 51.3 & 5.0 \\
\hline 8.0 & 4.6 & 4.6 & 55.1 & 6.0 & 1.9 & 70.0 & 5.0 \\
\hline 10.0 & 5.8 & 5.8 & 70.0 & 6.0 & 2.4 & 88.0 & 5.0 \\
\hline
\end{tabular}

account for any loss of water resulting from evapotranspiration. A base nutrient solution was prepared in each subsurface reservoir and was used to irrigate the seeds and developing seedlings for the first $10 \mathrm{~d}$ after sowing. The nutrient solution consisted of (in mmol): $2.3 \mathrm{Ca}^{2+}, 3.0 \mathrm{Mg}^{2+}, 10.5 \mathrm{Na}^{+}, 5.0 \mathrm{~K}^{+}$, $3.3 \mathrm{SO}_{4}{ }^{2-}, 13.3 \mathrm{Cl}^{-}, 5.0 \mathrm{NO}_{3}{ }^{-}$, and 0.34 $\mathrm{KH}_{2} \mathrm{PO}_{4}$. Micronutrients (in $\mu \mathrm{mol}$ ) based on Hoagland's micronutrient solution included100.0 iron as sodium ferric diethylenetriamine pentacetate (NaFeDTPA), 46.0 $\mathrm{H}_{3} \mathrm{BO}_{3}, 10.0 \mathrm{MnSO}_{4}, 0.8 \mathrm{ZnSO}_{4}, 0.4 \mathrm{CuSO}_{4}$, and $0.2 \mathrm{H}_{2} \mathrm{MoO}_{4}$ (Hoagland and Arnon, 1950). This base nutrient solution maintained an EC of $2.5 \mathrm{dS} \cdot \mathrm{m}^{-1}$ and served as the control solution. Preparations for this solution and subsequent salinity treatments accounted for the mineral composition already present in the municipal water for the city of Riverside (Carter and Grieve, 2008). pH was adjusted to 7.0 by the addition of $400 \mathrm{~mL}$ of $1 \mathrm{~N}$ $\mathrm{H}_{2} \mathrm{SO}_{4}$ per reservoir 1 week after planting.

Salinity treatments for each ionic water composition were applied $10 \mathrm{~d}$ after planting on 18 June 2004 when the first true leaves appeared. Target $\mathrm{EC}_{\mathrm{i}}$ levels were 4.0, 6.0, 8.0 , and $10.0 \mathrm{dS} \cdot \mathrm{m}^{-1}$ (Table 1). Salt solutions were added incrementally every other day to the reservoirs so that the highest salinity was reached on the seventh day so as to avoid salt shock to the seedlings. EC of the solution within each reservoir was monitored weekly using an Orion model 126 conductivity meter (Orion Research, Inc., Beverly, MA). Inductively coupled plasma optical emission spectrometry (ICPOES) was used to monitor and determine concentrations of calcium $(\mathrm{Ca})$, magnesium $(\mathrm{Mg})$, sodium $(\mathrm{Na})$, potassium $(\mathrm{K})$, total phosphorus $(\mathrm{P})$, total sulfur $(\mathrm{S})$, and $\mathrm{NO}_{3}$ in the irrigation water of each reservoir each week. Chlorine concentrations were analyzed using coulometric-amperometric titration (Carter and Grieve, 2008). Fifteen of the 40 plants for each cultivar in each tank were marked after the onset of first leaves so that weekly height measurements could be recorded throughout the course of the experiment. Although we do not present progressive height data in relationship to time in our findings, these were also the same plants that were harvested at the end of the experiment and were used to determine means of the phenotypic variables for each cultivar in each tank.

Except for evaporative coolers that mitigated extreme heat, environmental conditions in the greenhouse were monitored but not controlled. Temperature and relative humidity readings were automatically recorded hourly at a single point above the plant canopy from 8 June 2004 to 13 Aug. 2004. Average daytime temperature was $25.4{ }^{\circ} \mathrm{C}$ with a maximum of $35.5^{\circ} \mathrm{C}$ and a minimum of $17.8^{\circ} \mathrm{C}$. Average nighttime temperature was $20.7{ }^{\circ} \mathrm{C}$ with a maximum of $24.8^{\circ} \mathrm{C}$ and a minimum of $16.9^{\circ} \mathrm{C}$. Daytime relative humidity averaged $44.7 \%$ with a high of $48.2 \%$ and a low of $40.7 \%$. Nighttime relative humidity averaged $46.0 \%$ with a high of $48.4 \%$ and a low of $43.1 \%$. Average noontime photosynthetically active radiation was $962 \mu \mathrm{mol} \cdot \mathrm{m}^{-2} \cdot \mathrm{s}^{-1}$.

Analyses of minerals in plant tissues. On 7 July 2004, zinnia shoots were harvested for mineral analysis. The number of unmarked plants randomly harvested per cultivar from each tank (and, subsequently, three replicate tanks per treatment) ranged from 10 to 17 shoots to provide a minimum of $5 \mathrm{~g}$ of shoot material needed per cultivar per tank for mineral ion analysis. Fresh weight was determined at harvest to ensure a minimum of $5 \mathrm{~g}$ of material. Plants were triple-washed in deionized water, patted dry, and further dried in a forced-air oven for $72 \mathrm{~h}$ at $70{ }^{\circ} \mathrm{C}$. Dry weight of the shoots was recorded and plant material was ground in a Wiley mill to pass a 60-mesh screen. ICPOES was used to determine $\mathrm{Ca}, \mathrm{Mg}, \mathrm{Na}, \mathrm{K}$, total $\mathrm{S}$, and total $\mathrm{P}$ in the plant tissues by including a nitricperchloric acid digest; chlorine $(\mathrm{Cl})$ was determined by coulometric-amperometric titration from unfiltered nitric-acetic acid extracts. It is important to note that ICPOES does not measure the charged ion but the concentration of a particular mineral in solution. Because of this, we do not present the charge when referring to mineral content such as Ca content of shoots in the article.

Phenotypic data collection and statistical analyses. Phenotypic data were collected at 
the time of harvest. The 15 marked plants for each cultivar were harvested individually from each tank $\approx 2$ months after planting whenever flowers were fully mature and anthers were beginning to produce pollen. These 15 readings provided a single average value for each phenotypic parameter measured within each tank. At this time, data collected included: time to flowering, stem length, stem diameter (recorded at the soil line), internode length (recorded at the middle of the stem), inflorescence diameter, ray length, plant shoot fresh weight, number of leaves per plant, and number of shoots per plant.

For mineral analyses, a two-way fixedeffects analysis of variance (ANOVA) $(P=$ 0.05 , two-tailed) with a Type I sum of squares was applied to raw data for each mineral based on mean values of three tank replicates to assess whether differences occurred for ionic water composition [sea water dilution (SWD) or Colorado River water (CRW)] and salinity and to assess any interactions. Cultivars themselves were not compared so were not included in the analysis. When significant differences were found, a Tukey's multiple comparison procedure was used to compare individual means $(P=0.05$, two-tailed $)$. These same methods were applied to the phenotypic data for each character measured. Mean values for phenotypic data of each tank replicate were based on 15 marked plants. For each parameter measured, analyses were performed on raw data for three mean replicate tank values per treatment. All data were analyzed with SAS release 8.2 using proc GLM (SAS Institute, 2001). Selectivity coefficients $\left(S_{k, N a}\right)$ for both cultivars were calculated by the $\mathrm{K} / \mathrm{Na}$ ratio in the plant divided by the $\mathrm{K} / \mathrm{Na}$ ratio of the external media (Flowers and Yeo, 1988).

\section{Results}

Analyses of minerals in plant tissues. For both cultivars, $\mathrm{Mg}, \mathrm{Cl}, \mathrm{Na}$, and total $\mathrm{S}$ concentrations showed general increases in plant tissues as salinity increased in the irrigation water for both water types. However, $\mathrm{Mg}$ and total $\mathrm{S}$ increases were not significant for plants grown in SWD and for $\mathrm{Na}$ for plants grown in CRW (Tables 2 and 3). Conversely, for plants exposed to CRW, $\mathrm{Ca}, \mathrm{K}$, and total $\mathrm{P}$ concentrations decreased as salinity increased in the irrigation water. No significant changes were found for these minerals in plants exposed to SWD (Tables 2 and 3) or for the uptake of total P in 'Golden Yellow' plants exposed to CRW (Table 3).

ANOVA results show that for 'Salmon Rose', salinity had a significant effect on accumulation of $\mathrm{Mg}, \mathrm{Na}, \mathrm{K}, \mathrm{Cl}$, total $\mathrm{P}$, and total S. Water ionic composition significantly affected $\mathrm{Ca}, \mathrm{K}$, and total $\mathrm{S}$ uptake. Significant two-way interactions between salinity and water ionic composition were found for $\mathrm{Mg}$, $\mathrm{K}, \mathrm{Cl}$, total $\mathrm{P}$, and total S (Table 2).

ANOVA results show that for 'Golden Yellow', salinity had a significant effect on $\mathrm{Ca}, \mathrm{Mg}, \mathrm{Na}, \mathrm{K}, \mathrm{Cl}$, and total $\mathrm{S}$ accumulation, whereas ionic water composition had a significant effect on the accumulation of $\mathrm{Ca}$, $\mathrm{Mg}, \mathrm{Na}, \mathrm{K}$, and total S. Significant interactions between salinity and ionic water composition were found for $\mathrm{Mg}, \mathrm{Na}, \mathrm{K}, \mathrm{Cl}$, and total S. Total $\mathrm{P}$ was unaffected by either salinity or ionic water composition or their interaction (Table 3).

Both zinnia cultivars showed a strong preference for $\mathrm{K}$ over $\mathrm{Na}$ in both water compositions as shown by the selectivity coefficient values that increase as salinity increases (Table 4). In CRW, 'Salmon Rose' coefficients ranged from 102 to 239 in 2.5 and $10.0 \mathrm{dS} \cdot \mathrm{m}^{-1}$, respectively, and 'Golden Yellow' coefficients ranged from 159 to 367 in 2.5 and $10.0 \mathrm{dS} \cdot \mathrm{m}^{-1}$, respectively. In SWD, 'Salmon Rose' coefficients ranged from 118 to 268 in 2.5 and $10.0 \mathrm{dS} \cdot \mathrm{m}^{-1}$, respectively, and 'Golden Yellow' coefficients ranged from 128 to 385 in 2.5 and $10.0 \mathrm{dS} \cdot \mathrm{m}^{-1}$, respectively. 'Golden Yellow' had a higher selectivity for K over Na than 'Salmon Rose' (Table 4).

Phenotypic measurements. For both cultivars, growth parameters tended to decrease as salinity increased in both irrigation water types (Tables 5 and 6). Results of the twoway ANOVA show that for 'Salmon Rose', salinity significantly affected stem length, stem diameter, internode length, inflorescence diameter, ray length, and shoot fresh weight. Ionic water composition had a significant effect on stem length, stem diameter, internode length, shoot fresh weight, and number of shoots. Significant two-way interactions between salinity and ionic water composition were found for stem length, internode length, and shoot fresh weight. Time to flowering and number of leaves were unaffected by salinity, water ionic composition, or their interaction (Table 5). 'Salmon Rose' plants flowered 59 to $63 \mathrm{~d}$ after sowing.

For 'Golden Yellow', salinity significantly affected stem length, stem diameter, internode length, inflorescence diameter, ray length, and shoot fresh weight. Ionic water composition had a significant effect on stem length, stem diameter, internode length, shoot fresh weight, and leaf number. Significant two-way interactions between salinity and water ionic composition were found for stem length, stem diameter, internode length, and shoot fresh weight. Time to flowering and number of shoots were unaffected by salinity, water ionic composition, or their interaction (Table 6). 'Golden Yellow' plants flowered 54 to $59 \mathrm{~d}$ after sowing.

\section{Discussion}

Ion analysis. Ca concentrations in plant tissues significantly decreased when irrigated with increasing concentrations of CRW. Although non-significant, we found an overall decrease in Ca concentrations in plant tissues for plants irrigated with dilutions of SWD. The greatest decrease seemed to be at 10

Table 2. Effect of increased salinity on shoot mineral concentrations (values are the means of three observations \pm SE) in 'Salmon Rose' in response to two saline water ion compositions: concentrations of Colorado River water (CRW) and sea water dilutions (SWD). ${ }^{\mathrm{z}}$

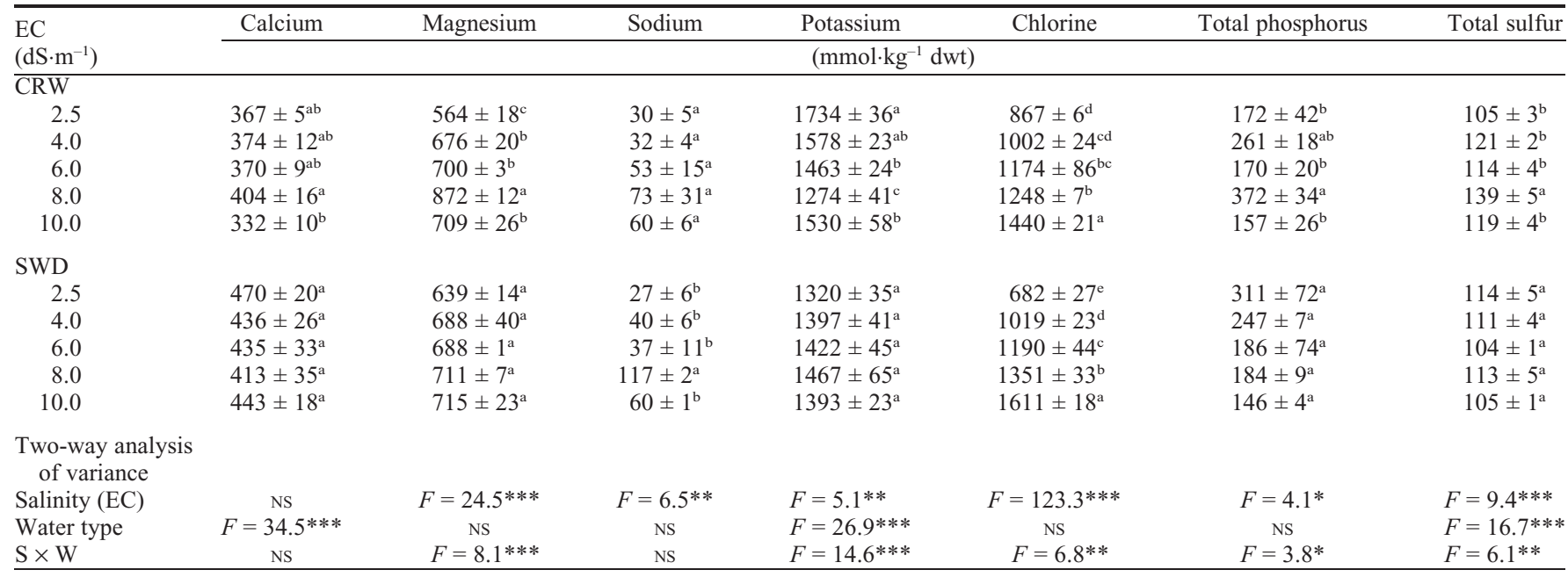

${ }^{\mathrm{z}}$ Different superscripts indicate statistically significant differences $(P<0.05)$ among electrical conductivity (EC) levels within a given water composition as a result of Tukey's. $F$-values from two-way analyses of variance are also included for each mineral tested.

${ }^{*} P<0.05 ; * * P<0.01 ; * * * P<0.001 ;$ NS $=$ non-significant. 
Table 3. Effect of increased salinity on shoot mineral concentrations (values are the means of three observations \pm SE) in 'Golden Yellow' in response to two saline water ion compositions: concentrations of Colorado River water (CRW) and sea water dilutions (SWD). ${ }^{z}$

\begin{tabular}{|c|c|c|c|c|c|c|c|}
\hline \multirow{2}{*}{$\begin{array}{l}\mathrm{EC} \\
\left(\mathrm{dS} \cdot \mathrm{m}^{-1}\right)\end{array}$} & Calcium & Magnesium & Sodium & Potassium & Chlorine & Total phosphorus & Total sulfur \\
\hline & \multicolumn{7}{|c|}{$\left(\mathrm{mmol} \cdot \mathrm{kg}^{-1} \mathrm{dwt}\right)$} \\
\hline \multicolumn{8}{|l|}{$\overline{\mathrm{CRW}}$} \\
\hline 2.5 & $351 \pm 27^{\mathrm{ab}}$ & $516 \pm 15^{\mathrm{c}}$ & $19 \pm 4^{\mathrm{a}}$ & $1729 \pm 30^{\mathrm{a}}$ & $963 \pm 23^{c}$ & $195 \pm 27^{\mathrm{a}}$ & $95 \pm 1^{\mathrm{c}}$ \\
\hline 4.0 & $415 \pm 27^{\mathrm{a}}$ & $641 \pm 1^{b}$ & $29 \pm 5^{a}$ & $1536 \pm 32^{b}$ & $1099 \pm 16^{\mathrm{bc}}$ & $211 \pm 54^{\mathrm{a}}$ & $109 \pm 2^{b c}$ \\
\hline 6.0 & $379 \pm 5^{\mathrm{ab}}$ & $708 \pm 13^{b}$ & $29 \pm 8^{a}$ & $1543 \pm 8^{\mathrm{b}}$ & $1172 \pm 25^{\mathrm{bc}}$ & $181 \pm 15^{\mathrm{a}}$ & $107 \pm 5^{\mathrm{bc}}$ \\
\hline 8.0 & $403 \pm 7^{a}$ & $836 \pm 15^{\mathrm{a}}$ & $26 \pm 1^{\mathrm{a}}$ & $1374 \pm 26^{\mathrm{c}}$ & $1242 \pm 67^{\mathrm{ab}}$ & $337 \pm 60^{\mathrm{a}}$ & $133 \pm 6^{\mathrm{a}}$ \\
\hline 10.0 & $314 \pm 12^{b}$ & $670 \pm 20^{b}$ & $41 \pm 7^{a}$ & $1641 \pm 31^{\mathrm{ab}}$ & $1409 \pm 82^{\mathrm{a}}$ & $190 \pm 27^{\mathrm{a}}$ & $116 \pm 1^{\mathrm{ab}}$ \\
\hline \multicolumn{8}{|l|}{ SWD } \\
\hline 2.5 & $444 \pm 8^{a}$ & $580 \pm 27^{\mathrm{a}}$ & $27 \pm 5^{\mathrm{b}}$ & $1431 \pm 8^{a}$ & $764 \pm 34^{c}$ & $241 \pm 78^{\mathrm{a}}$ & $104 \pm 1^{\mathrm{a}}$ \\
\hline 4.0 & $452 \pm 1^{\mathrm{a}}$ & $678 \pm 19^{a}$ & $32 \pm 16^{\mathrm{b}}$ & $1409 \pm 6^{\mathrm{a}}$ & $895 \pm 34^{\mathrm{bc}}$ & $213 \pm 54^{\mathrm{a}}$ & $103 \pm 3^{\mathrm{a}}$ \\
\hline 6.0 & $406 \pm 39^{\mathrm{a}}$ & $646 \pm 26^{a}$ & $23 \pm 2^{b}$ & $1548 \pm 59^{\mathrm{a}}$ & $1106 \pm 42^{\mathrm{b}}$ & $274 \pm 52^{\mathrm{a}}$ & $102 \pm 3^{a}$ \\
\hline 8.0 & $434 \pm 6^{a}$ & $659 \pm 17^{\mathrm{a}}$ & $99 \pm 5^{a}$ & $1489 \pm 27^{a}$ & $1391 \pm 33^{a}$ & $161 \pm 24^{\mathrm{a}}$ & $106 \pm 3^{a}$ \\
\hline 10.0 & $417 \pm 2^{\mathrm{a}}$ & $679 \pm 5^{a}$ & $43 \pm 2^{b}$ & $1436 \pm 58^{\mathrm{a}}$ & $1532 \pm 92^{\mathrm{a}}$ & $154 \pm 30^{\mathrm{a}}$ & $106 \pm 1^{\mathrm{a}}$ \\
\hline
\end{tabular}

Two-way analysis

of variance

Salinity (EC)

Water type

$F=3.3^{*}$
$F=23.4^{* * *}$

$F=34.5 * * *$

$F=6.44^{*}$

$F=20.1 * * *$
$F=15.1 * *$
$F=13.5 * * *$

$F=5.7 * *$

$F=20.8 * * *$
$F=42.1 * * *$
NS
$F=5.1 * *$

$F=11.5^{* * *}$

$\begin{array}{ll}\text { NS } & F=10.9 * * * \\ \text { NS } & F=15.2 * * * \\ \text { NS } & F=8.54 * *\end{array}$

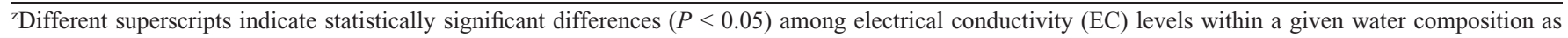
a result of Tukey's. $F$-values from two-way analyses of variance are also included for each mineral tested.

$* P<0.05 ; * * P<0.01 ; * * * P<0.001 ;$ Ns $=$ non-significant.

Table 4. K/Na selectivity coefficients for 'Salmon Rose' and 'Golden Yellow'.

\begin{tabular}{|c|c|c|c|c|c|}
\hline \multirow{2}{*}{$\begin{array}{l}\text { Electrical } \\
\text { conductivity } \\
\left(\mathrm{dS} \cdot \mathrm{m}^{-1}\right)\end{array}$} & \multirow[b]{2}{*}{$\mathrm{K} / \mathrm{Na}_{\mathrm{ext}}$} & \multicolumn{2}{|c|}{ Salmon Rose } & \multicolumn{2}{|c|}{ Golden Yellow } \\
\hline & & $\mathrm{K} / \mathrm{Na}_{\text {plant }}$ & $\overline{S_{K, N a}}$ & $\mathrm{~K} / \mathrm{Na}_{\text {plant }}$ & $\overline{S_{K, N a}}$ \\
\hline \multicolumn{6}{|l|}{$\overline{\mathrm{CRW}}$} \\
\hline 2.5 & 0.571 & 58 & 102 & 91 & 159 \\
\hline 4.0 & 0.287 & 49 & 171 & 53 & 185 \\
\hline 6.0 & 0.186 & 28 & 151 & 53 & 285 \\
\hline 8.0 & 0.138 & 17 & 123 & 53 & 384 \\
\hline 10.0 & 0.109 & 26 & 239 & 40 & 367 \\
\hline \multicolumn{6}{|l|}{ SWD } \\
\hline 2.5 & 0.414 & 49 & 118 & 53 & 128 \\
\hline 4.0 & 0.219 & 35 & 160 & 44 & 201 \\
\hline 6.0 & 0.148 & 38 & 257 & 67 & 453 \\
\hline 8.0 & 0.109 & 13 & 119 & 15 & 138 \\
\hline 10.0 & 0.0857 & 23 & 268 & 33 & 385 \\
\hline
\end{tabular}

${ }^{\mathrm{z} C o e f f i c i e n t s}\left(S_{\mathrm{K}, \mathrm{Na}}\right)$ were calculated from the $\mathrm{K} / \mathrm{Na}$ ratio of the plant divided by the $\mathrm{K} / \mathrm{Na}$ ratio of the external media that represented two saline water ion compositions: concentrations of Colorado River water (CRW) and sea water dilutions (SWD).

$\mathrm{dS} \cdot \mathrm{m}^{-1}$ for both water compositions. These findings are consistent with other investigations of cut flowers irrigated with saline water. Carter et al. (2005a, 2005b) found that $\mathrm{Ca}$ decreased in cut flower plant tissues as substrate salinity increased. Maas and Grieve (1987) found a $\mathrm{Na}^{+}$-induced $\mathrm{Ca}^{2+}$ deficiency in corn and explain that a high $\mathrm{Na}^{+} / \mathrm{Ca}^{2+}$ ratio causes nutritional imbalances, $\mathrm{Ca}^{2+}$ deficiencies, and disrupts the selective permeability of cell membranes. Suarez and Grieve (1988) explain that at high $\mathrm{Na}^{+}$concentrations, plant root membranes lose their integrity and are unable to regulate ion uptake, so $\mathrm{Ca}^{2+}$ selectivity is impaired. These findings differ from Carter and Grieve (2008) who found that Ca uptake was unaffected, and actually increased, in snapdragons irrigated with SWD and CRW up to EC levels of $14.0 \mathrm{dS} \cdot \mathrm{m}^{-1}$.

Magnesium in leaf tissues tended to increase as substrate $\mathrm{Mg}$ concentrations increased. For both cultivars exposed to $\mathrm{CRW}$, increased $\mathrm{Mg}$ was found in plant tissues irrigated with waters up to $8.0 \mathrm{dS} \cdot \mathrm{m}^{-1}$ and a significant decrease was found at 10.0
$\mathrm{dS} \cdot \mathrm{m}^{-1}$. The irrigation water ratios for $\mathrm{Ca}^{2+} /$ $\mathrm{Mg}^{2+}$ ranged from $0.83: 1$ to $0.58: 1$ at 2.5 and $10.0 \mathrm{dS} \cdot \mathrm{m}^{-1}$, respectively, in CRW. Given these decreasing ratios, it is unlikely that $\mathrm{Ca}$ would outcompete $\mathrm{Mg}$ at uptake sites in the root zone as salinity increased, thereby allowing plants to accumulate higher concentrations of $\mathrm{Mg}$ in their tissues. Although no statistical differences were found for $\mathrm{Mg}$ in plant tissues exposed to SWD for either cultivar, a steady increase in $\mathrm{Mg}$ concentration was observed in plant tissues as salinity increased. The irrigation water ratios for $\mathrm{Ca}^{2+} / \mathrm{Mg}^{2+}$ were $1: 1$ at all EC levels for SWD (except for EC 2.5). This would most likely explain why $\mathrm{Mg}$ increases in plant tissues were not significant for those plants grown in SWD. These findings are similar to those Carter and Grieve (2008). Typically, under high $\mathrm{Ca}^{2+} / \mathrm{Mg}^{2+}$ ratios in substrate solutions, it would be expected that $\mathrm{Ca}^{2+}$ would outcompete $\mathrm{Mg}^{2+}$ on binding sites on the root plasma membrane (Marschner, 1995). However, our findings do not indicate that $\mathrm{Ca}$ is outcompeting $\mathrm{Mg}$ in this system.
$\mathrm{K}$ concentrations in both cultivars decrease in plants irrigated with CRW. However, at $10.0 \mathrm{dS} \cdot \mathrm{m}^{-1}, \mathrm{~K}$ concentrations increased significantly. Although no statistical differences were found for either cultivar exposed to SWD, a general increase was found in treatments up to $8.0 \mathrm{dS} \cdot \mathrm{m}^{-1}$ for 'Salmon Rose' and up to $6.0 \mathrm{dS} \cdot \mathrm{m}^{-1}$ for 'Golden Yellow'. Plants tended to increase the amount of $\mathrm{K}$ in their tissues thereafter. Under saline, and especially sodic, conditions, $\mathrm{K}^{+}$is usually outcompeted by $\mathrm{Na}^{+}$at binding sites at the root level (Maathuis and Amtmann, 1999; Tester and Davenport, 2003). In our investigation, $\mathrm{K}$ levels were held constant in all irrigation treatments as $\mathrm{Na}$ increased. We would have expected more drastic decreases in $\mathrm{K}$ in plant tissues as salinity increased in the irrigation solutions, as was found by Carter and Grieve (2008) and Carter et al. (2005a, 2005b). Their studies, however, did consider mineral uptake at EC levels much higher (up to 12.0, 20.0, and 14.0 $\mathrm{dS} \cdot \mathrm{m}^{-1}$, respectively) than what we tested in this investigation. The increase of $\mathrm{Na}$ in plant tissues was marginal given the increase of $\mathrm{Na}$ in the nutrient solution. There obviously was little effect by $\mathrm{Na}$ on the uptake of $\mathrm{K}$ given that the overall concentrations for $\mathrm{K}$ remained high in plant tissues across all treatments, indicating high selectivity for $\mathrm{K}$ over $\mathrm{Na}$.

$\mathrm{Cl}$ concentrations increased significantly in both cultivars exposed to both irrigation solutions. This increase can be attributed to the increase of $\mathrm{Cl}$ in both irrigation solutions. Plants exposed to SWD also had higher concentrations of $\mathrm{Cl}$ in their shoot tissues than those exposed to CRW. SWD treatments had higher amounts of $\mathrm{Cl}$ in their compositions when compared with CRW, so we would expect higher amounts of $\mathrm{Cl}$ in these plants. Zinnia appears less selective with regards to $\mathrm{Cl}$ than to $\mathrm{Na}$ given the high concentration of $\mathrm{Cl}$ in plant tissues. 
Table 5. Effect of increased salinity on various plant measurements (values are the means of 15 observations in each of three replicate tanks $\pm \mathrm{SE}$ ) in 'Salmon Rose' in response to two saline water ion compositions: concentrations of Colorado River water (CRW) and sea water dilutions (SWD). ${ }^{z}$

\begin{tabular}{|c|c|c|c|c|c|c|c|c|}
\hline $\begin{array}{l}\mathrm{EC} \\
\left(\mathrm{dS} \cdot \mathrm{m}^{-1}\right)\end{array}$ & $\begin{array}{l}\text { Stem length } \\
(\mathrm{cm})\end{array}$ & $\begin{array}{l}\text { Stem diam } \\
\quad(\mathrm{mm})\end{array}$ & $\begin{array}{l}\text { Internode length } \\
(\mathrm{cm})\end{array}$ & $\begin{array}{l}\text { Inflorescence } \\
\text { diam }(\mathrm{cm})\end{array}$ & $\begin{array}{l}\text { Ray length } \\
\text { (mm) }\end{array}$ & $\begin{array}{l}\text { Shoot fresh } \\
\text { wt (g) }\end{array}$ & $\begin{array}{l}\text { Leaves } \\
\text { (no.) }\end{array}$ & $\begin{array}{l}\text { Shoots } \\
\text { (no.) }\end{array}$ \\
\hline 2.5 & $96 \pm 2^{\mathrm{a}}$ & $7.7 \pm 0.3^{\mathrm{a}}$ & $9.6 \pm 0.6^{\mathrm{a}}$ & $9.4 \pm 0.2^{\mathrm{a}}$ & $4.2 \pm 0.1^{\mathrm{a}}$ & $98 \pm 5^{\mathrm{a}}$ & $14 \pm 0.1^{\mathrm{a}}$ & $3.2 \pm 0.2^{\mathrm{a}}$ \\
\hline 4.0 & $83 \pm 1^{b}$ & $6.6 \pm 0.3^{\mathrm{ab}}$ & $6.3 \pm 0.2^{\mathrm{b}}$ & $9.6 \pm 0.1^{\mathrm{a}}$ & $4.3 \pm 0.1^{\mathrm{a}}$ & $79 \pm 8^{\mathrm{ab}}$ & $14 \pm 0.2^{\mathrm{a}}$ & $2.8 \pm 0.3^{\mathrm{a}}$ \\
\hline 8.0 & $57 \pm 2^{\mathrm{d}}$ & $5.2 \pm 0.1^{\mathrm{c}}$ & $2.9 \pm 0.2^{\mathrm{c}}$ & $8.2 \pm 0.3^{b}$ & $3.7 \pm 0.2^{\mathrm{b}}$ & $49 \pm 4^{b}$ & $15 \pm 0.5^{\mathrm{a}}$ & $2.6 \pm 0.1^{\mathrm{a}}$ \\
\hline 10.0 & $79 \pm 2^{\mathrm{bc}}$ & $6.0 \pm 0.4^{\mathrm{bc}}$ & $6.7 \pm 0.7^{\mathrm{b}}$ & $8.2 \pm 0.1^{\mathrm{b}}$ & $3.7 \pm 0.1^{\mathrm{b}}$ & $70 \pm 10^{\mathrm{ab}}$ & $14 \pm 0.3^{\mathrm{a}}$ & $3.3 \pm 0.3^{\mathrm{a}}$ \\
\hline \multicolumn{9}{|l|}{ SWD } \\
\hline 6.0 & $70 \pm 3^{\mathrm{a}}$ & $5.9 \pm 0.2^{\mathrm{a}}$ & $4.5 \pm 0.4^{\mathrm{ab}}$ & $8.9 \pm 0.6^{\mathrm{a}}$ & $4.0 \pm 0.3^{\mathrm{a}}$ & $64 \pm 5^{\mathrm{a}}$ & $15 \pm 0.5^{\mathrm{a}}$ & $2.7 \pm 0.1^{\mathrm{a}}$ \\
\hline 8.0 & $69 \pm 2^{\mathrm{a}}$ & $5.7 \pm 0.5^{\mathrm{a}}$ & $4.6 \pm 0.5^{\mathrm{ab}}$ & $8.4 \pm 0.4^{\mathrm{a}}$ & $3.8 \pm 0.1^{\mathrm{a}}$ & $61 \pm 5^{\mathrm{a}}$ & $14 \pm 0.5^{\mathrm{a}}$ & $2.9 \pm 0.3^{\mathrm{a}}$ \\
\hline 10.0 & $51 \pm 1^{\mathrm{b}}$ & $4.9 \pm 0.3^{\mathrm{a}}$ & $2.9 \pm 0.1^{\mathrm{b}}$ & $7.9 \pm 0.2^{\mathrm{a}}$ & $3.6 \pm 0.1^{\mathrm{a}}$ & $38 \pm 5^{\mathrm{a}}$ & $15 \pm 0.4^{a}$ & $2.1 \pm 0.2^{\mathrm{a}}$ \\
\hline \multicolumn{9}{|c|}{$\begin{array}{l}\text { Two-way analysis } \\
\text { of variance }\end{array}$} \\
\hline Salinity (EC) & $F=35.8^{* * *}$ & $F=7.5^{* * *}$ & $F=13.7 * * *$ & $F=8.4 * * *$ & $F=7.4 * * *$ & $F=6.3^{* *}$ & NS & NS \\
\hline
\end{tabular}

${ }^{2}$ Different superscripts indicate statistically significant differences $(P<0.05)$ among electrical conductivity $($ EC) levels within a given water composition as a result of Tukey's. $F$-values from two-way analyses of variance are also included for each character.

$* P<0.05 ; * * P<0.01 ; * * * P<0.001 ; \mathrm{NS}=$ non-significant.

Table 6. Effect of increased salinity on various plant measurements (values are the means of 15 observations in each of three replicate tanks \pm SE) in 'Golden Yellow' in response to two saline water ion compositions: concentrations of Colorado River water (CRW) and sea water dilutions (SWD). ${ }^{\mathrm{B}}$

\begin{tabular}{|c|c|c|c|c|c|c|c|c|}
\hline $\begin{array}{l}\text { EC } \\
\left(\mathrm{dS} \cdot \mathrm{m}^{-1}\right)\end{array}$ & $\begin{array}{l}\text { Stem length } \\
(\mathrm{cm})\end{array}$ & $\begin{array}{l}\text { Stem diam } \\
(\mathrm{mm})\end{array}$ & $\begin{array}{c}\text { Internode } \\
\text { length }(\mathrm{cm})\end{array}$ & $\begin{array}{l}\text { Inflorescence } \\
\text { diam }(\mathrm{cm})\end{array}$ & $\begin{array}{l}\text { Ray length } \\
\text { (mm) }\end{array}$ & $\begin{array}{l}\text { Shoot fresh } \\
\text { wt (g) }\end{array}$ & $\begin{array}{c}\text { Leaves } \\
\text { (no.) }\end{array}$ & $\begin{array}{l}\text { Shoots } \\
\text { (no.) }\end{array}$ \\
\hline 2.5 & $93 \pm 3^{\mathrm{a}}$ & $7.4 \pm 0.2^{\mathrm{a}}$ & $10.7 \pm 0.6^{\mathrm{a}}$ & $9.8 \pm 0.3^{\mathrm{a}}$ & $4.3 \pm 0.1^{\mathrm{a}}$ & $84 \pm 4^{a}$ & $14 \pm 0.3^{\mathrm{a}}$ & $3.1 \pm 0.2^{\mathrm{a}}$ \\
\hline 4.0 & $69 \pm 3^{b}$ & $6.6 \pm 0.0^{\mathrm{b}}$ & $6.4 \pm 0.4^{\mathrm{b}}$ & $9.7 \pm 0.1^{\mathrm{ab}}$ & $4.4 \pm 0.1^{\mathrm{a}}$ & $70 \pm 1^{\mathrm{ab}}$ & $13 \pm 0.1^{\mathrm{a}}$ & $2.8 \pm 0.2^{\mathrm{ab}}$ \\
\hline 8.0 & $46 \pm 1^{c}$ & $5.5 \pm 0.2^{\mathrm{c}}$ & $2.7 \pm 0.1^{\mathrm{c}}$ & $8.7 \pm 0.1^{\mathrm{b}}$ & $4.0 \pm 0.0^{\mathrm{a}}$ & $42 \pm 1^{c}$ & $14 \pm 0.5^{\mathrm{a}}$ & $2.5 \pm 0.0^{\mathrm{b}}$ \\
\hline 10.0 & $74 \pm 2^{\mathrm{b}}$ & $5.6 \pm 0.2^{\mathrm{bc}}$ & $6.5 \pm 0.3^{\mathrm{b}}$ & $8.9 \pm 0.3^{b}$ & $4.0 \pm 0.2^{\mathrm{a}}$ & $61 \pm 5^{\mathrm{b}}$ & $14 \pm 0.1^{\mathrm{a}}$ & $2.8 \pm 0.1^{\mathrm{ab}}$ \\
\hline \multicolumn{9}{|l|}{ SWD } \\
\hline 6.0 & $58 \pm 2^{\mathrm{b}}$ & $5.8 \pm 0.3^{\mathrm{ab}}$ & $4.5 \pm 0.6^{\mathrm{a}}$ & $9.5 \pm 0.3^{\mathrm{a}}$ & $4.3 \pm 0.1^{\mathrm{a}}$ & $51 \pm 6^{\mathrm{ab}}$ & $14 \pm 0.3^{\mathrm{a}}$ & $2.6 \pm 0.2^{\mathrm{a}}$ \\
\hline 8.0 & $63 \pm 2^{\mathrm{ab}}$ & $5.8 \pm 0.3^{\mathrm{ab}}$ & $4.1 \pm 0.0^{\mathrm{a}}$ & $8.9 \pm 0.3^{\mathrm{ab}}$ & $4.0 \pm 0.1^{\mathrm{ab}}$ & $56 \pm 5^{\mathrm{ab}}$ & $15 \pm 0.3^{\mathrm{a}}$ & $2.8 \pm 0.1^{\mathrm{a}}$ \\
\hline 10.0 & $46 \pm 1^{\mathrm{c}}$ & $5.0 \pm 0.1^{\mathrm{b}}$ & $3.2 \pm 0.3^{\mathrm{a}}$ & $8.1 \pm 0.2^{\mathrm{b}}$ & $3.7 \pm 0.1^{\mathrm{b}}$ & $37 \pm 3^{b}$ & $15 \pm 0.3^{\mathrm{a}}$ & $2.6 \pm 0.2^{\mathrm{a}}$ \\
\hline
\end{tabular}

Two-way analysis

of variance

Salinity (EC)

Water type

$F=46.2^{* * *}$

$F=21.9^{* * *}$

$F=23.7^{* * *}$

$\mathrm{S} \times \mathrm{W}$

$F=57.1^{* * *}$

$F=10.5^{* *}$

$F=58.4 * * *$

$F=12.9^{* * *}$

$F=12.36^{* * *}$
NS

$F=12.9^{* * *}$

$F=18.4^{* * *}$

NS

NS $\quad F=5.0^{* *}$

NS
$F=8.4^{* *}$

NS

${ }^{2}$ Different superscripts indicate statistically significant differences $(P<0.05)$ among electrical conductivity (EC) levels within a given water composition as a result of Tukey's. $F$-values from two-way analyses of variance are also included for each character.

$* P<0.05 ; * * P<0.01 ; * * * P<0.001 ;$ NS $=$ non-significant.

We expected similar increases in $\mathrm{Na}$ in plant tissues but found no significant increase for either cultivar irrigated with CRW, although increases were evident. These increases can be directly related to the increase in $\mathrm{Na}$ in the irrigation water. For plants irrigated with SWD, we also observed increases in $\mathrm{Na}$ concentrations in plant tissues. We also found that for both cultivars exposed to SWD, a significant increase was found at $8.0 \mathrm{dS} \cdot \mathrm{m}^{-1}$ but not at $10 \mathrm{dS} \cdot \mathrm{m}^{-1}$. It is interesting that an increase to $117 \mathrm{mmol} \cdot \mathrm{kg}^{-1}$ dry weight ( $\mathrm{dw}$ ) would be found at $8 \mathrm{dS} \cdot \mathrm{m}^{-1}$ for 'Salmon Rose' and an increase to 99 mmol. $\mathrm{kg}^{-1} \mathrm{dw}$ for 'Golden Yellow' would be found at $8 \mathrm{dS} \cdot \mathrm{m}^{-1}$ followed by a sharp decrease to $60 \mathrm{mmol} \cdot \mathrm{kg}^{-1} \mathrm{dw}$ and $40 \mathrm{mmol} \cdot \mathrm{kg}^{-1}$ $\mathrm{dw}$, respectively, at $10 \mathrm{dS} \cdot \mathrm{m}^{-1}$. Routine analysis of our irrigation solutions indicated that all minerals met the target concentrations at each EC level. These findings differ from those found by Carter and Grieve (2008) and Carter et al. (2005a, 2005b). They found sharp increases in $\mathrm{Na}$ concentrations in plant tissues as salinity increased, but the most drastic increases seemed to be in salinity levels above $10 \mathrm{dS} \cdot \mathrm{m}^{-1}$. Our results indicate that zinnias have an ability to exclude $\mathrm{Na}$, which appears to be associated with high selectivity for K. Higher plants have evolved mechanisms to avoid the adverse effects of $\mathrm{Na}^{+}$, including regulation of $\mathrm{Na}^{+}$entry into root epidermal and cortical cells, $\mathrm{Na}^{+}$compartmentation, and/or subsequent control of $\mathrm{Na}^{+}$loading to the xylem sap at the root level, thereby preventing transport of this potentially toxic ion to the aerial parts of the plant (Plett and Møller, 2010; Shannon, 1997; Zhang et al., 2010). The negative effects of $\mathrm{Na}^{+}$usually are alleviated by the addition of $\mathrm{Ca}^{2+}$ to the external solution (Tester and Davenport, 2003).
No significant differences were found in concentrations in total P for 'Golden Yellow' exposed to either irrigation water type. Similarly, no significant differences were found in total P for 'Salmon Rose' irrigated with SWD. We did find significant differences for 'Salmon Rose' irrigated with CRW. Sharpley et al. (1992) linked reduced amounts of $\mathrm{P}$ in plant tissues to the formation of $\mathrm{Ca}_{3}\left(\mathrm{PO}_{4}\right)_{2}$ in irrigation water when $\mathrm{Ca}^{2+}$ was increased along with inorganic phosphate. Grattan and Grieve (1999) explain that P concentrations tend to decrease as salinity increases, but concentrations are still dependent on the age of the plant, the plant species and the type of cultivar tested, the composition and level of salinity, and the concentration of $\mathrm{P}$ in the substrate. Carter et al. (2005a, 2005b) found significant and steady declines in total $\mathrm{P}$ in plant tissues of Celosia argentea and Limonium perezii above control levels continuing 
up to salinity levels of 12.0 and $20.0 \mathrm{dS} \cdot \mathrm{m}^{-1}$, respectively. Interestingly, Carter and Grieve (2008) found total P concentrations of two cultivars of snapdragon to decline only after reaching salinity levels above $8.0 \mathrm{dS} \cdot \mathrm{m}^{-1}$.

Total $\mathrm{S}$ concentrations in plant tissues were found to not be statistically significant for either cultivar exposed to SWD. Those exposed to CRW increased significantly in their uptake of sulfur as salinity increased. These findings can be directly linked to the increase of $\mathrm{SO}_{4}^{2-}$ in the CRW irrigation solutions and the smaller concentration of $\mathrm{SO}_{4}{ }^{2-}$ in the SWD irrigation solutions. White and Broadley (2001) explain that plants also preferentially select for $\mathrm{SO}_{4}{ }^{2-}$ in the presence of $\mathrm{Cl}^{-}$. Based on our results, it is difficult to discern whether the lower concentration of $\mathrm{Cl}$ in plants irrigated with CRW is the result of a lower amount of $\mathrm{Cl}$ when compared with the concentration found in the SWD irrigation solutions or if a higher concentration of $\mathrm{SO}_{4}{ }^{2-}$ in the CRW solutions was inhibitory to uptake of $\mathrm{Cl}$ in plant tissues in both cultivars. Clearly, $\mathrm{Cl}$ continued to increase in plant tissues as salinity and $\mathrm{SO}_{4}{ }^{2-}$ increased in the substrate solutions. Our findings are similar to those by Carter and Grieve (2008) who found that selectivity of total $\mathrm{S}$ over $\mathrm{Cl}$ was not evident in two cultivars of snapdragon.

Phenotypic analysis. Product information from Johnny's Selected Seeds suggests that both cultivars grow to heights between 100 and $125 \mathrm{~cm}$ and produce flowering heads between 10 and $15 \mathrm{~cm}$. The longest stems produced in our study were in response to the control treatment: $96 \mathrm{~cm}$ for 'Salmon Rose' and $93 \mathrm{~cm}$ for 'Golden Yellow' for plants irrigated in CRW. Plants irrigated with SWD produced shorter stems overall, most likely as a result of the effects of $\mathrm{NaCl}$. Barr (1992) suggests that the minimum stem length needed for commercial production of cut flowers is $41 \mathrm{~cm}$ (16 in). Plants in all treatments had a minimal stem length of 46 $\mathrm{cm}$ and most were longer than $60 \mathrm{~cm}$. Based on stem length alone, both cut flower cultivars can be produced under saline conditions at least as high as $10 \mathrm{dS} \cdot \mathrm{m}^{-1}$. Plants with longer stems would permit long-distance shipping and plants that happened to be shorter could be sold in local markets. Because we found no differences in time to flowering, all stems can be harvested $\approx 2$ months after sowing. This time period ranges between 54 and $59 \mathrm{~d}$ for 'Golden Yellow' and 59 and $63 \mathrm{~d}$ for 'Salmon Rose'. All inflorescence diameters were at least $7.9 \mathrm{~cm}$ and most were wider than $8.4 \mathrm{~cm}$. Similar morphological findings in relation to increasing salinity have been shown for other cut flower crops, including celosia, limonium, snapdragon, and matthiola (Carter and Grieve, 2008; Carter et al., 2005a, 2005b; Grieve et al., 2006, 2008). These findings have important implications for growers given that there is little to no information regarding the production of cut flower zinnias under saline conditions.

Growers can use lower quality water to irrigate this cut flower crop in coastal regions where groundwater is affected by sea water intrusion and in inland areas where the sulfate- and chloride-dominated tail waters of the Colorado River are at least as high as $10 \mathrm{dS} \cdot \mathrm{m}^{-1}$. Growth parameters decreased overall as irrigation water salinity increased; however, marketable cut flowers based on stem length could still be produced. The uptake of ions in zinnia is affected by the mineral composition of the irrigation water, how these ions compete for uptake at the plant root zone, and the selectivity of binding sites as salinity increases.

\section{Literature Cited}

Barr, C. 1992. The kindest cuts of all: How to evaluate new crops. Greenhouse Mgr. 11:82-84.

Carter, C.T. and C.M. Grieve. 2006. Salt tolerance of floriculture crops, p. 279-287. In: Khan, M.A. and D. Weber (eds.). Ecophysiology of high salinity tolerant plants. Springer, Dordrecht, The Netherlands.

Carter, C.T. and C.M. Grieve. 2008. Mineral nutrition, growth, and germination of Antirrhinum majus L. (snapdragon) when produced under increasingly saline conditions. HortScience 43:710-718.

Carter, C.T., C.M. Grieve, J.A. Poss, and D.L. Suarez. 2005a. Production and ion uptake of Celosia argentea irrigated with saline wastewaters. Sci. Hort. 106:381-394.

Carter, C.T., C.M. Grieve, and J.A. Poss. 2005b. Salinity effects on emergence, survival and ion accumulation of Limonium perezii. J. Plant Nutr. 28:1243-1257.

Dole, J.M. and H.F. Wilkins. 1999. FloriculturePrinciples and species. Prentice Hall, Upper Saddle River, NJ.

Flowers, T.J. and A.R. Yeo. 1988. Ion relations of salt tolerance, p. 392-416. In: Baker, D.A. and J.L. Hall (eds.). Solute transport in plant cells and tissues. John Wiley and Sons, New York, NY.

Grattan, S.R. and C.M. Grieve. 1999. Salinitymineral nutrient relations in horticultural crops. Sci. Hort. 78:127-157.

Greenway, H. and R. Munns. 1980. Mechanisms of salt tolerance in nonhalophytes. Annu. Rev. Plant Physiol. 31:149-190.

Grieve, C.M., J.A. Poss, and C. Amrhein. 2006. Response of Matthiola incana to irrigation with saline wastewaters. HortScience 41:119-123.
Grieve, C.M., J.A. Poss, C.T. Carter, and P.J. Shouse. 2008. Modeling growth of Matthiola incana in response to saline wastewaters differing in nitrogen level. HortScience 43:17871793.

Hoagland, D.R. and D. Arnon. 1950. The water culture method for growing plants without soil. Calif. Agr. Exp. Sta. Cir. 347.

Lee, M.K. and M.S. van Iersel. 2008. Sodium chloride effects on the growth, morphology, and physiology of chrysanthemum (Chrysanthemum $\times$ morifolium). HortScience 43:18881891.

Maas, E.V. and C.M. Grieve. 1987. Sodium-induced calcium deficiency in salt-stressed corn. Plant Cell Environ. 10:559-564.

Maathuis, F.J.M. and A. Amtmann. 1999. $\mathrm{K}^{+}$ nutrition and $\mathrm{Na}^{+}$toxicity: The basis of cellular $\mathrm{K}^{+} / \mathrm{Na}^{+}$ratios. Ann. Bot. (Lond.) 84:123133.

Marschner, H. 1995. Mineral nutrition of higher plants. Academic Press, London, UK.

Monk, R. and H.B. Peterson. 1961. Flowers tolerant to salinity. Farm Home Sci. 22:17.

Plett, D.C. and I.S. Møller. 2010. $\mathrm{Na}^{+}$transport in glycophytic plants: What we know and would like to know. Plant Cell Environ. 33:612-626.

SAS Institute. 2001. SAS/STAT software. Version 8.2. SAS Institute, Cary, NC.

Shannon, M.C. 1997. Adaptation of plants to salinity. Adv. Agron. 60:75-120.

Sharpley, A.N., J.J. Meisinger, J.F. Power, and D.L. Suarez. 1992. Root extraction of nutrients associated with long-term soil management, p. 151-217. In: Hatfield, J.L. and B.A. Stewart (eds.). Adv. Soil Sci. Vol. 19. Limitations to plant growth. Springer-Verlag, New York, NY.

Shillo, R., M. Ding, D. Pasternak, and M. Zaccai 2002. Cultivation of cut flower and bulb species with saline water. Sci. Hort. 92:41-54.

Skimina, C.A. 1992. Recycling water, nutrients and waste in the nursery industry. HortScience 27:968-971.

Suarez, D.L. and C.M. Grieve. 1988. Predicting cation ratios in corn from saline solution composition. J. Expt. Bot. 39:605-612.

Suarez, D.L. and J. Simunek. 1997. UNSATCHEM: Unsaturated water and solute transport model with equilibrium and kinetic chemistry. Soil Sci. Soc. Amer. J. 61:16331646.

Tester, M. and R. Davenport. 2003. $\mathrm{Na}^{+}$tolerance and $\mathrm{Na}^{+}$transport in higher plants. Ann. Bot. (Lond.) 91:503-527.

Valdez-Aguilar, L.A., C.M. Grieve, and J. Poss. 2009. Salinity and alkaline $\mathrm{pH}$ in irrigation water affect marigold plants: I. Growth and shoot dry weight partitioning. HortScience 44:1719-1725.

White, P.J. and M.R. Broadley. 2001. Chloride in soils and its uptake and movement within the plant: A review. Ann. Bot. (Lond.) 88:967-988.

Zhang, J.L., T.J. Flowers, and S.M. Wang. 2010. Mechanisms of sodium uptake by roots of higher plants. Plant Soil 326:45-60. 